\title{
Gambaran Tingkat Pengetahuan Ibu tentang Obesitas pada Anak di Kota Manado Tahun 2015
}

\author{
${ }^{1}$ Nurlana Ali \\ ${ }^{2}$ Vivekenanda Pateda \\ ${ }^{2}$ Audrey Wahani
}

\author{
${ }^{1}$ Program Studi Pendidikan Dokter Fakultas Kedokteran Universitas Sam Ratulangi Manado \\ ${ }^{2}$ Bagian Ilmu Kesehatan Anak Fakultas Kedokteran Universitas Sam Ratulangi \\ Email: alinurlana316@gmail.com
}

\begin{abstract}
Obesity is a health problem and its number of cases is increasing worldwide. The prevalence of overweight and obesity in children in the world increased from $4.2 \%$ in 1990 to $6.7 \%$ in 2010 , and is expected to reach $9.1 \%$ in 2020 . This study was aimed to obtain the level of mothers' knowledge about obesity in children in Manado 2015. This was a descriptive study with a cross sectional design. Population were mothers who visited Puskesmas Bahu (primary health care). The instrument used in this research was an interview consisting of 19 questions. Samples were mothers who had their children visited Puskesmas Bahu, obtained by using simple random sampling technique. The results showed 91 mothers as respondents. The majority of respondents $(40.7 \%)$ had good knowledge about obesity in children. Among respondents with good knowledge, $23.8 \%$ were highly educated; age 20-30 years and 21-40 years had the same percentage (17.6\%); worked as private employment $(15.39 \%)$; and got information from print media (19.79\%). Conclusion: The majority of mothers whose children visited Puskesmas Bahu had good knowledge. Age, education, work, and sources of information became the benchmark for the level of knowledge about obesity in children.
\end{abstract}

Keywords: knowledge, obesity

\begin{abstract}
Abstrak: Obesitas merupakan masalah kesehatan yang jumlahnya meningkat diseluruh dunia. Prevalensi overweight dan obesitas pada anak di dunia meningkat dari 4,2\% di tahun 1990 menjadi $6,7 \%$ di tahun 2010, dan diperkirakan akan mencapai 9,1\% di tahun 2020. Penelitian ini bertujuan untuk mendapatkan gambaran tingkat pengetahuan ibu tentang obesitas pada anak di Kota Manado tahun 2015. Jenis penilitian ialah deskriptif dengan desain potong lintang. Populasi penelitian ialah ibu-ibu yang berkunjung ke Puskesmas Bahu. Sampel penelitian ialah ibu-ibu yang memiliki anak yang berkunjung ke Puskesmas Bahu Kota Manado dengan responden sebanyak 91 orang. Instrumen yang digunakan ialah wawancara yang terdiri dari 19 pertannyaan. Pengambilan sampel dengan menggunakan teknik simple random sampling. Hasil penelitian memperlihatkan pengetahuan ibu tentang obesitas pada anak yang terbanyak ialah baik sebanyak 37 responden (40,7\%). Tingkat pengetahuan baik terbanyak berdasarkan pendidikan yaitu pendidikan perguruan tinggi $(23,8 \%)$; usia 20-30 tahun dan 21-40 tahun memiliki persentase yang sama $(17,6 \%)$; pekerjaan swasta $(15,39 \%)$; dan sumber informasi dari media cetak (19,79\%). Simpulan: Mayoritas ibu dengan anak yang berkunjung ke Puskesmas Bahu Kota Manado memiliki pengetahuan baik. Usia, pendidikan, pekerjaan, dan sumber informasi menjadi tolok ukur tingkat pengetahuan ibu tentang obesitas pada anak.
\end{abstract}

Kata kunci: pengetahuan, obesitas 
Masalah gizi di Indonesia saat ini memasuki masalah gizi ganda. Artinya, masalah gizi kurang masih belum teratasi sepenuhnya, sementara sudah muncul masalah gizi lebih. Kelebihan gizi yang menimbulkan obesitas dapat terjadi baik pada anak-anak hingga usia dewasa. ${ }^{1}$

Obesitas merupakan masalah kesehatan yang jumlahnya meningkat diseluruh dunia. WHO (World Health Organization) menyatakan bahwa obesitas sudah menjadi wabah global dan menjadi problem kesehatan yang harus diatasi. Obesitas merupakan keadaan patologik yaitu dengan terdapatnya penimbunan lemak berlebihan dari yang diperlukan untuk fungsi tubuh normal. ${ }^{2-4}$

Kelebihan gizi yang menimbulkan obesitas dapat terjadi baik pada anak-anak hingga usia dewasa. Berdasarkan penelitan Wardlaw, hampir sekitar $40 \%$ anak obes dan sekitar $80 \%$ remaja obes akan menjadi obes pada usia dewasa. Penelitian yang dilakukan Wahlqvist mendapatkan bahwa status gizi lebih yang terjadi pada anak usia 7-9 tahun akan terus berlanjut sampai menjadi dewasa. ${ }^{5}$

Prevalensi overweight dan obesitas pada anak di dunia meningkat dari 4,2\% di tahun 1990 menjadi $6,7 \%$ di tahun 2010, dan diperkirakan akan mencapai $9,1 \%$ di tahun 2020. Berdasarkan data Riset Kesehatan Dasar (Riskesdas) 2013 didapatkan prevalensi obesitas pada anak balita di tahun 2007, 2010, dan 2013 berdasarkan berat badan menurut tinggi badan lebih dari $\mathrm{Z}$ zcore 2 menggunakan baku antropometri anak balita WHO 2005 berturut-turut $12,2 \%, 14,0 \%$, dan $11,9 \%$, serta pada anak berusia 5-12, 13-15, dan 16-18 tahun berturut-turut $8,8 \%, 2,5 \%$, dan $1,6 \%$ berdasarkan indeks massa tubuh menurut umur lebih dari $\mathrm{Z}$ score 2 menggunakan baku antropometri WHO 2007 untuk anak berumur 5-18 tahun. $^{6}$

Data yang dikumpulkan Himpunan Obesitas Indonesia (2008) berdasarkan data Departemen Kesehatan pada tahun 1993 memperlihatkan bahwa jumlah penyandang obesitas meningkat menjadi $6,3 \%$ untuk anak laki-laki dan $8 \%$ untuk anak perem- puan. Data baru yang dikumpulkan pleh Himpunan Obesitas Indonesia yakni tahun 2008 menunjukkan bahwa prevalensi obesitas untuk anak-anak pada sejumlah sekolah dasar di Indonesia ialah $12 \%$ dengan obesitas dan 9\% kegemukan dari 1,730 anak. $^{7}$

Obesitas pada anak-anak secara khusus akan menjadi masalah kesehatan karena obesitas merupakan faktor risiko dari berbagai masalah kesehatan yang biasanya dialami orang dewasa seperti diabetes mellitus, hipertensi dan kolesterol tinggi. World Health Organization (WHO) mengungkapkan anak-anak obesitas memiliki risiko tiga hingga lima kali lebih besar mengalami serangan jantung atau stroke. ${ }^{5,8}$

Perlu dilakukan pencegahan sejak dini untuk mengurangi tingkat prevalensi dalam rangka menciptakan sumber daya manusia yang lebih baik. Pendidikan khususnya tentang kesehatan merupakan upaya yang sangat penting sebagai tahap awal dalam mengubah perilaku seseorang atau masyarakat untuk menuju perilaku hidup sehat. Dengan demikian obesitas pada anak memerlukan perhatian yang serius dan melibatkan peran serta orang tua. ${ }^{5}$

\section{METODE PENELITIAN}

Jenis penelitian yang digunakan ialah deskriptif dengan desain potong lintang. Penelitian ini dilaksanakan di Puskesmas Bahu Kota Manado dengan sampel sebanyak 91 responden.

\section{HASIL DAN BAHASAN}

Dari 91 responden terdapat 37 responden $(40,7 \%)$ yang memiliki pengetahuan tentang obesitas dengan kategori baik, 33 responden $(36,3 \%)$ dengan kategori cukup, dan 21 responden $(23.1 \%)$ dengan kategori kurang (Tabel 1).

Dari 91 responden terdapat 34 responden $(37,4 \%)$ yang berusia antara 20 30 tahun, 39 responden $(42,9 \%)$ yang berusia antara 31-40 tahun, dan 18 responden $(19,8 \%)$ yang berusia antara $41-$ 50 tahun (Tabel 2)

Dari 91 responden, terdapat 9 responden $(9,9 \%)$ dengan pendidikan SD, 27 
responden $(29,7 \%)$ dengan pendidikan SLTP, 24 responden $(26,4 \%)$ dengan pendidikan SLTA, dan 31 responden $(34,1 \%)$ dengan pendidikan Perguruan Tinggi (Tabel 3).

Tabel 1. Pengetahuan responden

\begin{tabular}{ccc}
\hline Pengetahuan & Jumlah & \% \\
\hline Baik & 37 & 40,7 \\
Cukup & 33 & 36,3 \\
Kurang & 21 & 23,1 \\
Total & 91 & 100 \\
\hline
\end{tabular}

Tabel 2. Usia responden

\begin{tabular}{ccc}
\hline Usia & Jumlah & \% \\
\hline $20-30$ & 34 & 37,4 \\
$31-40$ & 39 & 42,9 \\
$41-50$ & 18 & 19,8 \\
Total & 91 & 100 \\
\hline
\end{tabular}

Tabel 3. Pendidikan responden

\begin{tabular}{ccc}
\hline Pendidikan & Jumlah & \% \\
\hline SD & 9 & 9,9 \\
SLTP & 27 & 29,7 \\
SLTA & 24 & 26,4 \\
Perguruan Tinggi & 31 & 34,1 \\
Total & 91 & 100 \\
\hline
\end{tabular}

Dari 91 responden terdapat 11 responden $(12,1 \%)$ yang memperoleh informasi dari teman/keluarga, 28 responden $(30,8 \%)$ dari tenaga kesehatan, 35 responden $(38,5 \%)$ dari media cetak, dan 17 responden $(18,7 \%)$ dari media elektronik (Tabel 4).

Tabel 4. Sumber informasi responden

\begin{tabular}{ccc}
\hline Sumber Informasi & Jumlah & $\mathbf{\%}$ \\
\hline Teman/keluarga & 11 & 12,1 \\
Tenaga kesehatan & 28 & 30,8 \\
Media cetak & 35 & 38,5 \\
Media elektronik & 17 & 18,7 \\
Total & 91 & 100 \\
\hline
\end{tabular}

Dari 91 responden terdapat 28 responden $(30,8 \%)$ yang merupakan ibu rumah tangga, 17 responden $(18,7 \%)$ yang bekerja sebagai PNS, 22 responden $(24,2 \%)$ sebagai karyawan swasta, 16 responden $(17,6 \%)$ sebagai wiraswasta, dan 8 responden $(8,8 \%)$ yang bekerja sebagai lainnya (Tabel 5).

Tabel 5. Pekerjaan responden

\begin{tabular}{ccc}
\hline Pekerjaan & Jumlah & \% \\
\hline Ibu Rumah Tangga & 28 & 30,8 \\
PNS & 17 & 18,7 \\
Swasta & 22 & 22,2 \\
Wiraswasta & 16 & 17,6 \\
Lainnya & 8 & 8,8 \\
Total & 91 & 100 \\
\hline
\end{tabular}

Tingkat pengetahuan baik terbanyak berdasarkan pendidikan yaitu pendidikan perguruan tinggi $(23,8 \%)$. Usia 20-30 tahun dan 21-40 tahun memiliki angka yang sama yaitu masing-masing 17,6 \%. Pekerjaan swasta dengan tingkat pengetahuan baik sebanyak $15,39 \%$. Sumber informasi dari media cetak memiliki tingkat pengetahuan baik sebanyak 19,79\%.

\section{SIMPULAN}

Berdasarkan hasil penelitian ini dapat disimpulkan bahwa sebagian besar ibu dengan anak yang berkunjung ke Puskesmas Bahu Kota Manado memiliki pengetahuan baik. Usia, pendidikan, pekerjaan, dan sumber informasi menja-di tolok ukur tingkat pengetahuan ibu tentang obesitas pada anak.

\section{DAFTAR PUSTAKA}

1. Sartika RAD. Faktor risiko obesitas pada anak 5-15 tahun di Indonesia. Makara Kesehatan. 2011;15(1):37-43.

2. WHO. Obesity: Preventing and managing the global epidemic. WHO Technical Report Series: Geneva, 2000.

3. Rumajar F, Rompas S, Babakal A. Faktor yang mempengaruhi obesitas pada anak TK Providensia Manado. Jurnal Keperawatan. 2015;3(3).

4. Soetjiningsih. Tumbuh Kembang Anak. Jakarta: EGC, 2012.

5. Marlissa EW, Pandelaki AJ, Ratag GA. Perilaku orang tua dan keluarga terhadap obesitas pada anak kelas 5 SD 
di SDN 70 Manado. Jurnal Kedokteran Komunitas dan Tropik. 2015;3(4): 22934.

6. IDAI. Diagnosis, tatalaksana dan pencegahan obesitas pada anak dan remaja. 2015. [cited 2015 Sept 16]. Available from: http://idai.or.id/wp-content/uploads/ 2015/05/buku-obes-0215.pdf
7. Permatasari IRI, Mayulu N, Hamel R. Analisa riwayat orang tua sebagai faktor risiko obesitas pada Anak SD di Kota Manado. eKp. 2013;1(1).

8. Irianto K. Gizi Seimbang dalam Kesehatan Reproduksi (Balanced Nutrion in Reprodective Health). Bandung: Alfabeta, 2014 